\title{
Dr. Vízkelety Tibor
}

\section{(1929-2017)}

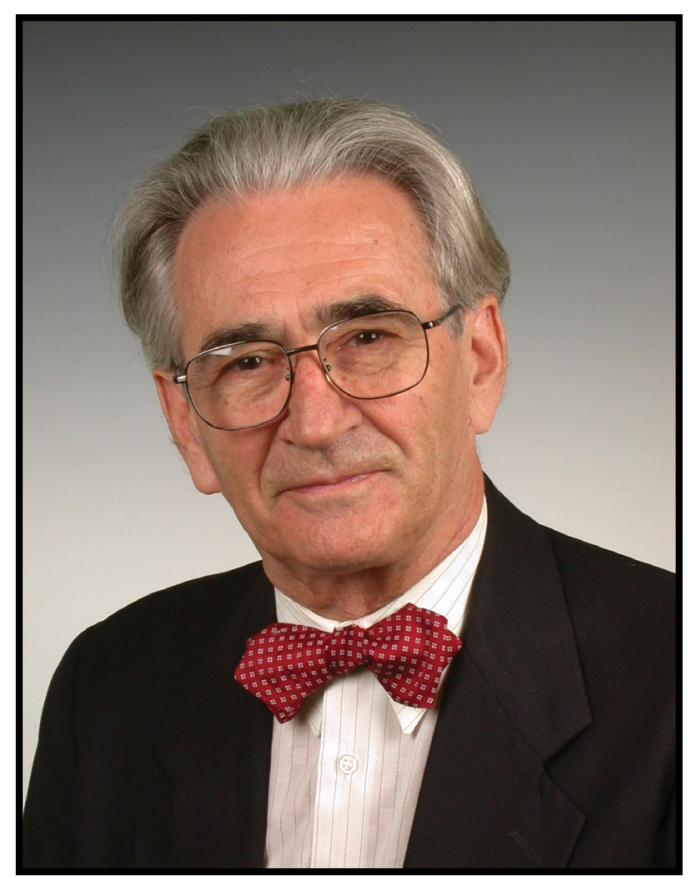

Mély megrendüléssel tudatjuk a magyar orvostársadalommal, hogy 2017. augusztus 24-én, 88 éves korában elhunyt Dr. Vízkelety Tibor, az Ortopédiai Klinika emeritus professzora. Türelemmel viselt hosszas betegséget követően otthonában, szerettei által körülvéve hunyt el. Tisztában voltunk azzal, hogy súlyos betegségben szenved, hogy egészségi állapota meggyengült, mégis megdöbbenéssel fogadtuk a hírt.

Vízkelety professzor úr több mint 50 éven át dolgozott a Semmelweis Egyetem Ortopédiai Klinikáján, ahová az Anatómiai Intézetben szerzett széles körü morfológiai ismeretekkel érkezett. Szakvizsgája után érdeklődése a gyermekortopédia felé fordult. Hihetetlen munkabírása és tanulni vágyása hamarosan a Gyermekosztály vezetőjévé tette. Gyógyító munkája középpontjában mindvégig a gyermekortopédia maradt. Közvetlen munkatársai szerint hihetetlen volt a munkabírása, számos dolgozat, disszertáció megszületésében múködött közre. Kivételes empátiával, szeretettel fordult a beteg gyermekek felé. Kevés orvosnak adatik meg, hogy tevékenysége össztársadalmi szinten alapjaiban változtassa meg egy betegség kezelési stratégiáját, lefolyását. Vízkelety professzornak ez megadatott: megszervezte országosan a csípőficam-szürővizsgálatokat, népszerúsítette a Pavlikkengyel használatát, bevezette a korai mútéti repositiót. Számos eredeti megoldást dolgozott ki a végtagi fejlő- dési rendellenességek kezelésére és alkalmazta a neuromuscularis betegségben szenvedő gyermekek ellátásában a korszerú sebészeti módszereket.

Vízkelety professzor mint ízig-vérig egyetemi polgár, hivatásának tekintette a gyógyítás mellett az oktatást és beteganyagának tudományos igényü feldolgozását is. 1970-ben védte meg kandidátusi és 1989-ben doktori disszertációját. 1980-ban nevezték ki az Ortopédiai Klinika igazgatójává, mely pozíciót 15 éven keresztül töltötte be. A Magyar Ortopéd Társaság titkáraként, majd hosszú éveken át elnökeként számos hazai, illetve nemzetközi kongresszust szervezett nagy lelkesedéssel és elszántsággal. Több mint 140 közleménye igazolja, hogy tollát nem „íráskényszer”, hanem aktuális problémafelvetés, az orvosok képzése vezette. Számtalan könyvfejezet szerzősége mellett mindenképpen említésre méltó Gyermekortopédia címü könyve, szerkesztésében jelent meg $A z$ ortopédia tankönyve, mely három kiadást ért meg. Az 1990-ben kiadott Csont-izületi daganatok és daganatszerü elváltozások címü könyve hiánypótló volt.

Vízkelety professzor évtizedig tartó vezetői funkciója megteremtette a lehetőségét iskolateremtő személyiségének kibontakozására. Munkatársai közül hárman professzori címet nyertek el, négyen osztályvezetői fóorvosi beosztásba kerültek. Vízkelety professzor volt az ortopédia-gyermekortopédia országhatáron belüli és kívüli elismertségének a megteremtője. Minden erejével és lelkesedésével, számtalan alkalommal személyes anyagi áldozatot is hozva, arra törekedett, hogy nemzetközi kapcsolatokat kialakítva képviselhesse és elfogadtassa a hazai ortopédiát, megteremtve a hetvenes és nyolcvanas években a szakma fejlesztésének leghatékonyabb módját, a fiatal kollégák külföldi képzésének lehetőségét.

Vízkelety professzor kilenc évig volt a magyar ortopédia delegáltja az ortopéd világtársaságnál, a SICOT-nál, három évig bizottsági elnökként is dolgozott. Munkáját a SICOT vezetősége a Tiszteletbeli Tagság odaítélésével honorálta. Felismerve az európai ortopédia hálózata szervezésének jelentőségét, vezetésével a Magyar Ortopéd Társaság alapító tagja lett az EFORT-nak 199l-ben.

Tisztelt Professzor Úr! Örök Mentorunk!

Kedves Tanítónk és Példaképünk!

Emléked őrizni fogjuk, bennünk élsz tovább.

Hálás tanszékvezetői utódaid.

Szendröi Miklós dr. Szöke György $d r$. 